\title{
Fair Dealing and the World of Work ${ }^{1}$
}

\author{
Douglas Brodie
}

Stirling University

\section{Introduction}

A wide range of contracts provide for the provision of work. The common law of the employment contract will be relevant to some; others will be treated as commercial agreements and a different corpus of norms will be applicable. Conventional wisdom tells us that there is a strict dichotomy between employment and commercial law; they regulate relationships which are different in nature and underpinned by different values. The dichotomy seems starker still when one takes into account the statutory rights possessed by employees; the rights and duties owed by virtue of an employment contract are radically different compared to a contract for services and the relationship which ensues is of a fundamentally different character. However, if one simply focusses on the common law of contracts for the provision of work it is evident that the dichotomy is something of a false one. It is probably not possible to identify terms whose presence is consistent with a contract of employment but not one for services. ${ }^{2}$ The high degree of similitude is reflected in the fact that a fundamental element of both contracts is that they involve the exchange of work for payment. ${ }^{3}$ Again there is a great deal of commonality where core default rules are concerned; at least where the economic elements of the bargain are in issue rather than the more personal ones. For instance, where the default rules in respect of allocation of risk are concerned, both contracts require that performance will be discharged with reasonable care which ensures that the risk of poor performance lies with either the employee or independent contractor. There have, at least up until recently, been considerable differences where the personal dimension is concerned in that the obligation of mutual trust and confidence has been held not to apply outwith the employment relationship. ${ }^{4}$ Again the employer's

\footnotetext{
${ }^{1}$ Professor Guy Davidov was kind enough to critically comment upon an earlier draft of this paper and I am also indebted to the editor and the anonymous referee for a number of very helpful cooments; the responsibility is mine alone. I am also very grateful to Professor Breen Creighton for bringing the decision in Commonwealth Bank v Barker [2013] FCAFC 83 to my attention and to Professor David Campbell for allowing me sight of his forthcoming article: Good Faith and the Ubiquity of the 'Relational' Contract' (2014) 76 MLR.

${ }^{2}$ Likewise where contracts for semi-dependent workers are concerned: M.Freedland, The Personal Employment Contract, (Oxford: OUP 2003) Ch 3.

${ }^{3}$ Collins argues that the difference between the two contracts 'does not derive from the terms of the contract, for both envisage an exchange of services for payment. H.Collins, 'Market Power, Bureaucratic Power and the Contract of Employment' (1986) 15 ILJ 1, 9.

${ }^{4}$ Bedfordshire CC v Fitzpatrick Contractors (1999) 62 Construction Law Reports 64.
} 
obligations to protect the self-employed worker by taking reasonable care for his health and safety are much more circumscribed than is the case where the employee is concerned.

Contracts of employment and those for services have much in common; more in fact than they have apart. Inevitably any exercise in comparison of contractual terms will fail to generate clear demarcation lines; the true point of departure lies in the fact that hitherto the law of contracts for services has been informed by the values of commercial law. Questions of implication and construction may therefore be resolved quite differently. The reason that mutual trust and confidence does not apply to a relationship of self-employment is because the relationship is entered into at arms-length and implication would conflict with fundamental notions of caveat emptor that are inherent (statute and equitable intervention apart) in common law conceptions of economic freedom. ${ }^{5}$ It is worth recalling that as recently as 2002 the Privy Council reaffirmed the 'general principle that an express and unrestricted power cannot in the ordinary way be circumscribed by an implied qualification. ${ }^{6}$ At common law it is for the parties to judge whether the terms of a commercial exchange are satisfactory and judicial intervention is unlikely to be seen as appropriate.

I would suggest though that traditional thinking seems increasingly outdated as the common law is evolving to a position whereby contracts for the provision of work are underpinned by shared rather than divergent values. This paper seeks to explore the implications of this evolution with particular attention being given to both the employment contract and the contract for services.

\section{Divergence in Values}

Ironically the current trend towards convergence has been preceded by a period of greater divergence as, over the last thirty years or so, the employment/commercial dichotomy appeared to have become more accentuated as the law of the employment contract evolved to incorporate significant elements of good faith. Freedland and Kountouris observing that the `English law of contracts of employment has tended to be perceived as more specialized and distinctive as time has gone on. ${ }^{77}$ In the UK judicial recognition of the significance of the peculiarities of the employment contract led to the contract evolving in a way that necessitated modification of general contractual principles. Scally $v$ Southern Health

\footnotetext{
${ }^{5}$ Royal Botanic Gardens v South Sydney City Council (2002) 240 CLR 45.

${ }^{6}$ Reda v Flag Ltd Bermuda [2002] IRLR 747.

${ }^{7}$ M. Freedland and N.Kountouris, The Legal Construction of Personal Work Relations, (Oxford: OUP, 2011), 185.
} 
Board $^{8}$ and Malik $v B C C I^{9}$ are landmark decisions on this journey. Similarly, in a highly influential decision in Wallace v United Grain Growers, the Canadian Supreme Court held that employers owed an obligation of good faith with respect to the manner of dismissal, the breach of which was to be compensated for by adding to the length of the notice period. ${ }^{10}$ In justifying this position Iacobucci J. noted that the contract of employment had a number of characteristics that set it apart from commercial contracts. In particular, 'the terms of the employment contract rarely result from an exercise of free bargaining power in the way that the paradigm commercial exchange between two traders does. Individual employees on the whole lack both the bargaining power and the information necessary to achieve more favourable contract provisions than those offered by the employer, particularly with regard to tenure.' In addition, Iacobucci J. stressed that the power imbalance continues to affect the conduct of the relationship after the contract has been entered into.

Good faith, and the obligation of mutual trust and confidence in particular, has assumed a central role in the life of the employment contract and has acted, and continues to act, as a catalyst for further evolution at common law. One illustration of this is the way in which the implied obligation of fidelity has been strengthened and come to demand more by way of propriety where a senior employee is concerned: 'Whilst it would be over simplistic to say that the more senior an employee, the greater the degree of loyalty and diligence required of him, the scope of the duty imposed on someone at high managerial level in a multimillion pound business will involve a heavy burden not to do anything which might result in damage to the interests of that business. ${ }^{11}$ Popplewell $\mathrm{J}$ suggesting that a senior manager who became aware of a competitive threat to an aspect of the business for which he is responsible would normally come under such a duty, whereas a junior employee without such responsibility would not. The fact that good faith has been placed at the core of the employment relationship has led to the obligations assumed by senior employees moving closer to those owed by fiduciaries. A similar process has taken place in Canada where the courts have gone even further and

\footnotetext{
8 [1992] 1 AC 294.

9 [1998] 1 AC 20.

${ }^{10}$ [1997] 3 S.C.R. 701. And see Honda Canada v Keays [2008] 294 DLR (4th) 577.

${ }^{11}$ Imam-Sadeque v Bluebay [2013] IRLR 344; Collidge v Freeport [2007] EWHC 1216. And see M.Freedland and N.Kountouris, above n.7.
} 
held that some senior employees should indeed be regarded as fiduciaries. The pivotal decision being Canadian Aero Service v O'Malley where the Canadian Supreme Court approved the view of Gower that fiduciary `duties, except in so far as they depend on statutory provisions expressly limited to directors, are not so restricted but apply equally to any officials of the company who are authorised to act on its behalf, and in particular to those acting in a managerial capacity. ${ }^{12}$ The impact of O'Malley has been very considerable but also problematic in that definitional issues have abounded: it has proved very difficult to find a convincing basis upon which to distinguish between those who are senior managers and those who are not. Second... the range of employees who have been caught is extensive.' ${ }^{13}$ Canadian experience may make it more likely that the courts in the UK will decide against developing a discrete body of default rules for senior managers. Instead the expectations now placed on such individuals may be more likely to influence the way in which the duty of fidelity is interpreted and applied in particular cases. ${ }^{, 14}$

The open-textured nature of the obligation of trust and confidence allows it to retain its vitality by a constant process of renewal in the light of changes in good practice in employment relations. ${ }^{15}$ The recent Australian decision in Commonwealth Bank v Barker requires that, in a redundancy situation, the employer should take steps to consult with the employee about the possibility of redeployment and to provide him with the opportunity to apply for suitable alternative positions. ${ }^{16}$ The decision accords with good practice in industrial relations and reflects mutual trust's origins in the duty of co-operation by requiring the employer to take positive steps without which the employee is unable to enjoy a right

\footnotetext{
12 [1973] 40 DLR (3d) 371.

${ }^{13}$ D. Brodie, 'The Employment Relationship and Fiduciary Obligations' (2012) 16 ELR 198, 203.

${ }^{14}$ Freedland, above n.1, 190.

${ }^{15}$ Yapp v FCO [2013] ICR D21 demonstrates the extent to which mutual trust and confidence has resulted in notions of natural justice being embedded in the employment contract: ' a golden thread through the case law on fair treatment is that those liable to be affected by a decision must be given prior notice of it so that they can make representations. A corollary is that any representations must be taken into account by the decision-maker. The greater detriment a decision is likely to cause the more demanding these duties.'

${ }^{16}$ Commonwealth Bank above n.1.
} 
or benefit conferred upon him by the contract. It is of note that the benefit under the contract was not a specific entitlement (as in Scally) but was conceived in terms of the totality of the employment relationship.

At first sight, the way in which the law of the employment contract has become increasingly informed by notions of good faith would not encourage the development of a hypothesis that a world of shared values is in prospect. However, of late, obligations of fair dealing have become more evident in other areas of the law of contract. It is my contention that this will result in the content of all contracts for the provision of work displaying a greater measure of good faith. A number of factors can be seen as responsible for this development but three in particular merit detailed discussion: the implications of a relationship being analogous to one of employment; the consequences of a contract being categorised as relational; and the validity of conventional assumptions about the role of good faith in the general principles of the law of contract.

\section{Analogous Relationships}

In some jurisdictions the courts have now acknowledged that the characteristics highlighted in Wallace can also be found in some types of contract which conventionally would be styled commercial; they are undoubtedly important characteristics where the employment contract is concerned but cannot be seen as unique. A highly significant example is the contract of franchise given that franchisees resemble functionaries for large capitalist corporations. ${ }^{17}$ In Shelanu Inc v Print Three Franchising Corp it was observed that the contract is one of 'adhesion... Further, insofar as access to information is concerned, the franchisee is dependent on the franchisor for information about the franchise, its location and projected cash flow, and is typically required to take a training program devised by the franchisor. The third characteristic, namely that the relationship continues to be affected by the power imbalance, is also met by the fact the franchisee is required to submit to inspections of its premises and audits of its books on demand, to comply with operation bulletins, and, often is dependent on, or

\footnotetext{
${ }^{17}$ A. Felstead, The Corporate Paradox: Power and Control in the Business Franchise (1993) 10.
} 
required to buy, equipment or product from the franchisor.' ${ }^{18}$ Those shared characteristics mean that the franchisee is vulnerable in very similar ways to the employee. As with employment there is much scope for unfair exercise of prerogative power on the part of the franchisor. The impact of an unfair or harsh termination will be felt very strongly in both cases. In Wallace it was said that the ’point at which the employment relationship ruptures is the time when the employee is most vulnerable and hence, most in need of protection. In recognition of this need, the law ought to encourage conduct that minimizes the damage and dislocation (both economic and personal) that result from dismissal ${ }^{19}$; these concerns would seem equally applicable to the franchisee. It should also be said that the franchisee may experience additional vulnerabilities compared to the employee; some face a double jeopardy in that they are both franchisees and tenants. Again, the fact that the franchisee will often be required to put up a significant amount of capital leaves them heavily exposed to the risk of opportunistic behaviour: 'The incentive that causes a business with sunk costs to stay in operation despite losses makes franchisees vulnerable to franchisor behaviour known as 'opportunism'. Because the franchisee will continue to operate even if it is not recovering its sunk investments, the franchisor can make decisions that induce such losses without the franchisee going out of business. When these decisions benefit the franchisor at the expense of the franchisee, the franchisor opportunistically extracts a portion of the franchisee's sunk costs. A franchisor can potentially extract this value from the franchise directly in a number of ways: it can raise the price of goods sold to franchisees, increase rent, boost royalties through an increase in the required volume of a franchise, levy fees or divert advertising funds to general corporate uses. Extractions can occur indirectly as well. To increase the price of new franchises, a franchisor could require franchisees to make excessive advertising investments, to participate in promotional programs which are not cost effective, or to undertake unnecessary renovations. ${ }^{20}$

The recognition of the existence and significance of shared characteristics has meant that in a number of jurisdictions good faith is adopting a more prominent role in a wider range of contracts. The journey in the UK that was prompted by the emergence of mutual trust and confidence is being replicated. Where a franchise is concerned the obligations imposed on the franchisor resemble those imposed on an employer by virtue of the latter obligation. In Far Horizons Pty v McDonald's Australia the court proceeded on the basis that franchise agreements contain an implied term 'of good faith and fair dealing which obliges each party to exercise the powers conferred upon it by the agreement in good

\footnotetext{
${ }^{18}$ Shelanu Inc v Print Three Franchising Corp 226 DLR $\left(4^{\mathrm{TH}}\right) 577$.

${ }^{19}$ Wallace, above n. 10, 95 .

${ }^{20}$ Report by the House of Representatives Standing Committee on Industry, Science and Technology May 1997: 'Finding a Balance: Towards Fair Trading in Australia', 3.24.
} 
faith and reasonably, and not capriciously or for some extraneous purpose. Such a term is a legal incident of such a contract. ${ }^{21}$ The range and outcome of issues dealt with in franchise disputes bears close parallels with the mutual trust and confidence case law. Discriminatory treatment of franchisees may give rise to breach of duty; ${ }^{22}$ the exercise of powers of unilateral variation is moderated by requirements of fair dealing. ${ }^{23}$ However, unconstrained by the challenges of achieving coherence between common law and statutory regimes, the courts have held that the capacity to terminate may be restricted. In Garry Rogers Motors v Subaru it was argued that the termination was in breach of contract because the implied obligation of good faith had been infringed. ${ }^{24}$ It was held that `There is no reason to think, prima facie at least, that the obligation of good faith and fair dealing would not act as a restriction on a power to terminate a contract, especially if that power is in general terms. ${ }^{25}$ However, on the facts, the obligation had not been breached. Unaffected by Johnson $v$ Unisys, the oddity of the position in the law of the employment contract whereby the point in the relationship where the weaker party is most vulnerable (i.e. termination) is not restricted by requirements of fair dealing is not replicated. ${ }^{26}$

The benefits of the protection afforded can be very considerable. The fact that the franchisor had used his powers for an improper purpose was found to be a breach of the implied term of fair dealing in Antony's Pierv HBC.${ }^{27}$ There it was held that withholding consent under an express clause (which provided for the approval by the land owner of the developer's plans) with a view to forcing financial concessions involved a breach of contract. A word of caution should be sounded; as in assessing the impact of mutual trust and confidence it is salutary to bear in mind that in some cases the outcome would have been the same had the decision been decided on a basis other than that of fair dealing. A

\footnotetext{
${ }^{21}$ [2000] VSC 310; Burger King Corp v Hungry Jack's Pty [2001] NSWCA 187.

22 J. Paterson, 'Implied Fetters on the Exercise of Discretionary Contractual Powers' (2009) 35 Monash ULR 45, 58 citing Kellcove v Australian Motor Industries (unreported, FCA, 6.7.1990) and Laurelmont v Stockdale \& Leggo [2001] QCA 212.

${ }^{23}$ J F Keir v Priority Management Systems [2007] NSWSC 789.

${ }^{24}$ [1999] FCA 903.
}

${ }^{25}$ Ibid at para 35. Similarly, in Mangrove Mountain Quarries v Barlow [2007] NSWSC 492 it was said that 'Acting in good faith means that a party to a contract should not pretend to rely upon breaches of no importance to him or her to achieve a collateral but desired result of bringing the contractual relationship to an end.' Again, in Meridian Retail Pty v Australian Unity Retail Network Pty [2006] VSC 223 it was said that 'in my opinion an implied obligation of good faith would preclude the franchisor from exercising, or threatening to exercise, its literally unqualified power under the franchise agreement ... in order to secure [the franchisees'] premature determination, negate their extended term and expropriate [their] interests at an undervalue.'

\footnotetext{
${ }^{26}$ [2003] 1 AC 518.

27411 Mass. 451 and discussed by T.Weigand, 'The Duty of Good Faith and Fair Dealing in Commercial Contracts in Massachsetts' (2004) 88 Mass. L.R. 1, 6.
} 
decision that a breach of contract has arisen given the improper use of powers conferred might be arrived at by construction of the terms concerned: 'If a contract confers power on a contracting party in terms wider than necessary for the protection of the legitimate interests of that party, the courts may interpret the power as not extending to the action proposed by the party in whom the power is vested or, alternatively, conclude that the powers are being exercised in a capricious or arbitrary manner or for an extraneous purpose, which is another way of saying the same thing. ${ }^{28}$

As with the employment contract the task of the adjudicator is eased by a willingness to generalise once one has identified a category of relationship that tends to contain a wide disparity of bargaining power. The courts tend not to differentiate between the positions of employees (despite the infinite variety of circumstances that arise in working life) but view them as a homogeneous class. ${ }^{29}$ Similarly, in Meridian Retail $\mathrm{v}$ Australian Unity Retail Network, it was said that it 'was not established that the franchisees, in the present case, were vulnerable or substantially disadvantaged in relation to the franchisor. Relevant authorities indicate, however, that the implication of an obligation of good faith may be particularly appropriate in the context of a franchise relationship, doubtless because it frequently embodies a significant disparity of bargaining power. ${ }^{30}$

I would maintain that the incorporation of an obligation of fair dealing into a type of contract which can be seen as analogous to employment is to be welcomed. The difference, for instance, between a contract of franchise and one of employment is a matter of form rather than substance: it appears that the definition of the franchisee as a separate firm, rather than as part of the franchisor, is a legal and not an economic distinction. ${ }^{31}$ By entering into a franchise the franchisor achieves vertical integration without responsibility; as much control is likely to exist over the franchisee as would be the case in an employment relationship. ${ }^{32}$ In Massey v Crown Life it was acknowledged that two individuals working side by side for the same employer may have a different status even though they discharged precisely the same functions.; one may be an employee whilst the other is self-employed. ${ }^{33}$ The same is true in the world of franchising: 'McDonald's stores in Australia fall into two classes. First there are those owned by McDonald's itself and conducted by it through employee managers and staff...The second

${ }^{28}$ Alcatel Australia v Scarcella (1998) 44 NSWLR 349. Again the same outcome might have been arrived at in some instances by the application of the long established implied obligation of co-operation.

${ }^{29}$ D.Brodie, Voice and the Employment Contract in A.Bogg and T.Novitz (eds) Voices at Work: Continuity and Change in the Common Law World (forthcoming: OUP 2014).

${ }^{30}$ Meridian Retail, above n.25.

${ }^{31}$ P. Rubin, 'The Theory of the Firm and the Structure of the Franchise Contract' (1978) 21 JLE 223, 233.

${ }^{32}$ Meridian Retail, above n. 25.

33 [1978] ICR 590. 
class comprises those stores conducted by independent operators under licence agreements such as those in this case. Each owner/operator conducts their own business, although they do so under very strict control and supervision by McDonald's. They are required under the terms of their licence agreement to conform to the requirements of McDonald's in nearly every aspect of their business. These requirements concern food type and standards, kitchen and service areas, the manner, presentation and sale of food, the design, appearance and standard of the premises including adjacent parking areas, hours of trading, staffing including training and presentation, and financial reporting. ${ }^{34}$

A franchise agreement often simply gives rise to an employment relationship by another name with the corollary that the franchisee will be as vulnerable as an employee. Abuse of superior bargaining power should be addressed irrespective of the way in which the working relationship is constituted by the employer. The Privy Council decision in Caltex $v$ Feenan dealt with a solus agreement and illustrates this very well. ${ }^{35}$ The claimants had agreed to supply petrol bought from Caltex at a service station leased from them. The contract involved would have been categorised as commercial but obliged the claimants to provide labour (formally the obligation was not to provide their own though the practical reality was different). The Privy Council found that operating through this medium meant that labour costs may be less than where employees are hired directly. In addition, the employer gained not only the licence fee and rental of goodwill but procured an assured and profitable outlet for their products without incurring the expense of paying wages to employees for doing what, under the solus contract, the Feenans had bound themselves to do instead.' It is important that the law affords protection in situations of this type to ensure that those providing labour are not exploited. In Caltex the terms of the contract made it inevitable that the claimants would themselves have to perform the work required to discharge the obligations set out in the solus agreement: 'The Feenans undertook to conduct the business on the premises during all lawful hours and to use their best endeavours to secure any necessary authority or permission to secure that those lawful hours should be as long as possible.' They lived, in effect, the lives of employees and like many employees found themselves working excessive hours for limited reward.

\section{Relational Contracts}

Shenelau, by looking to analogous relationships, can be seen as expounding a more general principle than that found in $W$ allace; its application though is restricted to agreements that exhibit particular

\footnotetext{
${ }^{34}$ Far Horizons, above n. 18, para 3.

${ }^{35}$ [1981] 1 WLR 1003.
} 
features. A broader and more inclusive approach can also be detected. Both the employment contract and a franchise agreement can be categorised as relational contracts. The recent decision in Yam Seng v ITC involved a distribution agreement and it was held that there was an implied term that the parties would deal with each other in good faith. ${ }^{36}$ One of the key factors in favour of this outcome was the fact that the agreement was seen as relational and implication was seen as furthering the values of such contracts: `The parties are not aiming at utility-maximisation directly through the performance of specified obligations; rather, they are aiming at utility-maximisation indirectly through long term cooperative behaviour manifested in trust and not in reliance on obligations specified in advance'. An obligation of good faith is consistent with a key tenet of relational contract theory; i.e. that a contract is a ‘undamentally co-operative exchange relationship. ${ }^{37}$ Two words of caution might be uttered. First, judgments which adopt the terminology of relational contracts remain relatively rare; the only decision of note in the employment context is Johnson. ${ }^{38}$ Even where the terminology is deployed we cannot be sure of the extent of shared understanding. Second, it is not immediately apparent that all commercial parties would share the values held by the parties in Yam Seng; reasonable people will differ over what is required by `reasonable commercial standards of fair dealing. ${ }^{39}$ There is much to be said for Brownsword's view that in different times and in different places, commercial standards might implicate thicker or thinner views of co-operative entitlements and responsibilities. ${ }^{40}$ It is perfectly conceivable that in a future dispute categorisation of a commercial contract as relational would be consistent with the court determining the matter by reference to a different set of norms. For some, the practical implementation of relational contract theory is predicated on translating the practice of the parties into legal obligations: the 'oughts' of relational contract are 'the product of what appears actually to work in social interaction'. ${ }^{41}$ Ultimately, it is for the courts to exercise a value judgment as to which behaviours should be treated as prescriptive. If the practice of the parties does not lead to implication on traditional grounds (e.g. through incorporation by course of dealing) there can be no guarantee that depicting the contract as relational will do so. I am far from convinced that it is axiomatic that categorisation as relational allows one to conclude that an obligation of fair dealing

\footnotetext{
${ }^{36}$ [2013] EWHC 111. For further discussion see Campbell, above n.1 and S.Whittaker, 'Good faith, implied terms and commercial contracts' (2013) 129 LQR 463.

${ }^{37}$ Campbell, above n.1.

38 Johnson, above n.26.

${ }^{39}$ CPC Group Ltd v Qatari Diar Real Estate Investment Co [2010] EWHC 1535.

${ }^{40}$ R. Brownsword in Contract and Economic Organisation (D. Campbell and P.Vincent-Jones (eds)) 27. In Esso Australia Resources $v$ Southern Pacific Petroleum [2005] VSCA 228, para 3 it was said that 'If a duty of good faith exists, it really means that there is a standard of contractual conduct that should be met. The difficulty is that the standard is nebulous. Therefore, the current reticence attending the application and recognition of a duty of good faith probably lies as much with the vagueness and imprecision inherent in defining commercial morality.'

${ }^{41}$ I. R. Macneil, The New Social Contract (New Haven: Yale University Press, 1980) 408.
} 
arises.

\section{Fair Dealing}

A third factor which explains the movement towards greater convergence in the values of contracting parties is the growing acceptance that a norm of fair dealing is part and parcel of commercial contracting in general. This can be seen at international level where good faith type obligations are increasingly to be found in key codes and conventions. Waddams highlights the fact that good faith is regarded by the Draft Common Frame of Reference `as part of the underlying principle of justice.' ${ }^{42}$ Again, Freedland and Kountouris point to the 'quite...vigorous development of notions of good faith and fair dealing in European systems of private law.' ${ }^{43}$ At the level of specific jurisdictions a comparative excursus also confirms that such instruments are not confined to civilian systems; a number of common law systems embody a norm of good faith in their commercial law. The US is a notable example given that both the Uniform Commercial Code and the Restatement (Second) of Contracts are of this ilk. It is difficult to gauge how influential the international and comparative position has been but the strong degree of consensus conveys a very cogent message. Against that backdrop, we find that fair dealing has come much more to the fore in commercial law in the UK. Since Reda was decided the law of commercial contracts has become increasingly willing to incorporate obligations of this nature dealing. Cases such as the decision of the Court of Appeal in Socimer International Bank v Standard Bank, which dealt with a commercial contract between two banks, hold that discretionary provisions are now regulated in a manner similar to the way that they would be if they arose in the employment contract: 'Where A and B contract with one another to confer a discretion on A, that does not render B subject to A's uninhibited whim. In my judgment, the authorities show that not only must the discretion be exercised honestly and in good faith, but, having regard to the provisions of the contract by which it must be conferred, it must not be exercised arbitrarily, capriciously, or unreasonably. ${ }^{44}$ Indeed in the Court of Appeal in Mid Essex v Compass Group Jackson LJ went so far as to suggest that such `a term is extremely difficult to exclude, although I would not say it is utterly impossible to do so. ${ }^{35}$ This overstates the current position but does testify to the growing acceptance that disputes should be determined by reference to fair dealing. Something in the way of a process of cross-fertilisation may be underway. In_upholding the contention that an implied term of

\footnotetext{
${ }^{42}$ S. Waddams, Principle and Policy in Contract Law (2011) 213.

${ }^{43}$ Freedland and Kountouris, above n.7, 197.

${ }^{44}$ [2008] EWCA Civ 116.

${ }^{45}$ [2013] EWCA Civ 200, para 83.
} 
good faith existed in Yam Seng developments in a number of areas, including the law of the employment contract, were looked to. The fact that a modification of general contractual principles has functioned successfully in a specific type of contract makes it more likely that in turn it will provide the catalyst for the transformation of other nominate contracts or indeed the general principles themselves. ${ }^{46}$ The conceptualisation of sham contracts that took place in Autoclen₹v Belcher ${ }^{47}$ can be seen in this light as it was facilitated by prior developments in the law of landlord and tenant. ${ }^{48}$

In addition, the courts may see themselves as reflecting changes in the practices and values of the parties and not simply imposing judicial conceptions of appropriate behaviour. In Yam Seng, the question of implication, as with questions of construction, was determined on a contextual basis. Crucially, the values of the commercial parties helped inform that context: 'the relevant background against which contracts are made includes not only matters of fact known to the parties but also shared values and norms of behaviour. Some of these are norms that command general social acceptance; others may be specific to a particular trade or commercial activity...'. The decision in favour of implication of an obligation of good faith was seen as according with the values of the world of commerce (though it is not clear how those values were ascertained). Somewhat contradictorily, the term was viewed as an implied term in fact as the law of commercial contracts was not seen at a stage of development whereby it could apply as a matter of generality and therefore be classified as an implied term in law. ${ }^{49}$ It is certainly highly debateable whether commercial contracts can be viewed as a homogeneous class. ${ }^{50}$

It might of course be said that such decisions are no more than further instances of the conventional English approach of fashioning `piecemeal solutions in response to demonstrated problems of unfairness ${ }^{51}$ or, adopting a more positive outlook, instances of specific duties which do the useful part

\footnotetext{
${ }^{46}$ In Park Cakes v Shumba [2013] EWCA Civ 974 Lord Underhill drew attention to the absence of an 'articulated conceptual underpinning' in the single employer custom case of Albion Automotive $v$ Walker [2002] EWCA Civ 946. The law of unilateral contracts may provide the answer: D.Brodie, 'Reflecting the dynamics of employment relations' (2004) 33 ILJ 159, 163.

${ }^{47}$ [2011] ICR 1157. And see A.Bogg, 'Sham Self-Employment in the Supreme Court' (2012) 41 IJL 328.

${ }^{48}$ AG Securities $v$ Vaughan [1990] 1 A.C. 417

${ }^{49}$ This would appear to be correct: Mid Essex above n. 44. Again, in Hamsard 3147 v Boots UK [2013] EWHC 325 , Norris J declined to find that Yam Seng was 'authority for the proposition that in commercial contracts it may be taken to be the presumed intention of the parties that there is a general obligation of "good faith".'

${ }^{50}$ R. Hooley, 'Controlling Contractual Discretion' (2013) 72 CLJ 65.

${ }^{51}$ Interfoto Picture Library v Stiletto Visual Programmes_[1989] 1 QB 433, 439.
} 
of the work of good faith. ${ }^{52}$ However, the steadily increasing weight of case law may lead to the emergence of an overarching principle of good faith. Certainly, when we take into account the way in which the law of contract in similar common law systems has developed it does not seem fanciful to suggest that such a norm is likely to become part of the law of commercial contracts sooner rather than later. Australian experience indicates that once disputes begin to be adjudicated by reference to a norm of fair dealing it is not long before that norm becomes embedded. There has been a radical shift of position in Australia over the last 20 years and 'fundamental notions of caveat emptor' now seem utterly anachronistic. The decision in Rennard Constructions (ME) Pty Limited v Minister for Public Works has proved to be highly influential; there it was said that 'people generally, including judges and other lawyers, from all strands of the community, have grown used to the courts applying standards of fairness to contract which are wholly consistent with the existence in all contracts of a duty upon the parties of good faith and fair dealing in its performance. In my view this is in these days the expected standard, and anything less is contrary to prevailing community expectations.' ${ }^{53}$ Since then there have been numerous decisions of the Australian courts that have regulated the dealings of commercial parties by reference to implicit obligations of fair dealing. ${ }^{54}$ It would be erroneous to describe the law as settled (a decision of the High Court would be beneficial) but it does seem highly unlikely that the world of traditional contracting will be restored. The case law exhibits a degree of uncertainty over whether implication is contingent upon the presence of inequality of bargaining power. The most that can be said is that the existence of disparity makes it more likely that an obligation of fair dealing will be held to exist. There has also been a measure of controversy with respect to whether the obligation of fair dealing should be seen as in implied term in fact or law. This reflects the fact that commercial relationships are now seen as much more diffuse and it does not make sense to treat them as a singular class.

\section{Fairer Contracting?}

In Australia and Canada good faith has much to say about the way in which a contract for work should be conducted. Analysis of case law in the UK indicates a trend towards fair dealing playing a greater part in such disputes but, beyond the employment contract, the law is still in a decidedly embryonic stage. Up until now, for instance, a franchise contract appears to have been viewed as a commercial

${ }^{52}$ D.Campbell, above n.1.

53 (1992) 26 NSWLR 234.

${ }^{54}$ See, for instance, Paterson, above n. 22. 
agreement. In cases involving the enforceability of restrictive covenants the contract has been treated as analogous to the goodwill cases rather than ones dealing with the employment contract. ${ }^{55}$ Similarly, attempts to suggest that a franchise agreement is subject to the obligation of mutual trust and confidence have foundered because the relationship was seen as commercial in nature. ${ }^{56}$

I would suggest that this is likely to change sooner rather than later where the relationship can be viewed as analogous to employment. The incremental approach to the extension of $W$ allace which took place in Shelanu is an attractive and convincing one. The problems faced by the weaker party are of a broadly similar nature and it is equitable that parity of protection is afforded. The characteristics which are shared generate common problems; common solutions will often be apposite. Such a development of the law would not be dependent on the recognition of an overarching principle of good faith. As with the emergence of mutual trust and confidence the approach in Shelanu is firmly grounded in the values of the common law which "... will not permit abuse of power. This is the basis of judicial review, and it reflects also the basis of all those private law doctrines where public policy has been held to restrain one man's hold over another" ${ }^{\prime 57}$.

Some relationships might be thought to be closely analogous to employment; Freedland's concept of the semi-dependent worker comes to the fore at this juncture. ${ }^{58}$ Mutual trust and confidence might readily attach to such a relationship given it `may actually be a personal one and a high-trust one to the same extent as the fully dependent work relationship. Indeed, some semi-dependent workers' contracts may embody more personal and even, in a sense, higher trust relationships that some contracts of employment. ${ }^{59}$ More generally, deciding whether a relationship is analogous to employment may not be altogether straightforward. I would submit that the position adopted in Shelanu is compelling where a franchise is concerned. What though of a contract for services? As already discussed, if one

\footnotetext{
${ }^{55}$ Kall-Kwik Printing v Rush [1996] FSR 114.

56 Jani-King (GB) v Pula Enterprises [2007] EWHC 2433.

${ }^{57}$ Sir John Laws, 'Public Law and Employment Law: Abuse of Power [1997] PL 455, 464.

${ }^{58}$ Freedland, above n.1, 28. Such a worker would be employed under a contract for work 'to be carried out normally in person and not in the conduct of an independent business or professional practice.'

$59 \mathrm{lbid}$ at $169-170$.
} 
approaches the issue through a comparison of the terms of the contracts it would be easy to conclude that an analogous relationship has been shown to exist. However, the position of an individual entering into a contract for services might be thought to be very different from situations where the services are provided by a corporate body. In the former case one could readily assume (as with employment and franchise) that inequality of bargaining power and all its attendant problems existed. In such cases the incorporation of a term of fair dealing seems highly justifiable. Quite clearly one could not make the same assumptions where a corporate body was concerned.

Recent developments in tort law also raise questions about the position of the contract for services. There the courts are now prepared to extend the categories of relationship for which a defendant is vicariously liable to include those ‘akin to that between an employer and an employee'. JGE $v$ English Province of our Lady of Charity concerned the responsibility of the bishop of the diocese for a parish priest whose appointment did not give rise to a contractual relationship; the priest holding nothing other than ecclesiastical office. ${ }^{60}$ The Court of Appeal had to determine, by way of a preliminary question, whether vicarious liability could still arise. The conventional response would have been no. However, a majority of the court held that the relationship was so close in character to one of employment that it was just and fair to hold the defendant vicariously liable. This might be thought to be a somewhat surprising outcome as the `relationship was significantly different from that between an employer and an employee. ${ }^{61}$ So far as future cases are concerned, Ward LJ (who gave the leading judgment)tells us that one should seek to identify 'the broad characteristics of the employer/employee relationship' and ask whether the contract in issue 'bears a sufficiently close resemblance and affinity in character' to one of employment. This approach was approved by the Supreme Court in Various Claimants $v$ Catholic Child Welfare Society but will without doubt prove troublesome. ${ }^{62}$ The vagaries of the test will, without doubt, encourage counsel to challenge current orthodoxies. It has already been argued that vicarious

\footnotetext{
60 [2012] PIQR P19.

${ }^{61}$ Lord Hope, 'Tailoring the law on vicarious liability' (2013)129 LQR 514, 523

${ }^{62}$ [2013] 3 WLR 1319.
} 
liability can now arise with respect to a prisoner. ${ }^{63}$ It is striking that JGE confirms that the employer is not liable for the activities of independent contractors; thereby denying the existence of perhaps the clearest analogy. This conclusion was reached even though the Court of Appeal acknowledged that the endeavours of the self-employed may be just as central to the success of the enterprise as those of employees: the employer may have as close a connection with his regularly used independent contractor as he has with an employee who is but an anonymous member of his workforce.'

I would suggest though that the position adopted by the law of vicarious liability will not diminish the force of arguments by analogy where the law of the contract is concerned. Vicarious liability is an area where policy considerations dominate and JGE may simply reflect the long established orthodoxy that, for a variety of reasons, the employer is not vicariously liable for an independent contractor. The policy issues which are relevant to the formation of default rules for contracts for work are of a different order. It is also the case that the increasing emphasis on enterprise liability may lead to a reassessment of the traditional position in tort. The latter doctrine has led to an expansion of the types of behaviour that lead to liability; it is equally relevant to the identification of relationships that render the employer responsible. I would suggest that maintaining that relationships of self-employment are not caught by an 'akin to employment' test is unstable and likely to be sustainable. ${ }^{64}$

\footnotetext{
${ }^{63}$ In Cox v Ministry of Justice [2013] EW Misc 1, while working as a catering manager at HM Prison Swansea, the claimant suffered injury in an accident caused by the negligence of a prisoner who was carrying out paid work under her supervision. She argued, in reliance upon Various Claimants that the defendant was vicariously liable for the negligence of the prisoner. The claim failed as the relationship was viewed as being explicable on the basis of penal policy.

${ }^{64}$ The extension of the law of non-delegable duties in Woodland $v$ Essex CC [2013] UKSC 66 to render the defendant strictly liable for the behaviour of an independent contractor may be noted. It may be argued that, rather than adding a further exception, it would have made more sense for the law on vicarious liability to reassess whether the employer should be liable for contractors. Baroness Hale observing in Woodland that some of the traditional arguments against the imposition of liability may no longer hold good 'in today's world where large organisations may well outsource their responsibilities to much poorer and un- or under-insured contractors.' Cleightonhills v Bembridge Marine [2012] EWHC 3449 found, obiter, that the employer should be treated as vicariously for someone who had been self-employed.
} 


\section{The Contract for Services Revisited}

Against this backdrop, where the law of contract is concerned, I would suggest that an individual entering into a contract for services is likely to be held to be in a position analogous to the employee. Contracts where the services are provided by a corporate body lie at the other end of the spectrum and such a relationship would only fully take on board a norm of good faith when contract law as a whole adopts an overarching principle. There is a myriad of intermediate positions which render generalisation problematic. Where individuals are concerned I would anticipate that a default rule of fair dealing will emerge shortly. It is already the case that the content of contracts for the provision of work display a great deal of commonality and further convergence would be a perfectly natural development. As I have discussed, it had previously been thought that matters might be somewhat different where the personal elements of the contract for services were concerned and, in particular, that the implied term of mutual trust and confidence had no application. This outcome can be justified on the basis that the implication of the term assumes the existence of a contract involving personal relations. However, I would argue that the existence of disparity in bargaining power and the consequent risk of abuse of power are sufficient in themselves to justify a norm of fair dealing being required. The element of personal relations in the employment relationship should be seen as an additional reason for the importation of an obligation of mutual trust. Of course a number of mutual trust cases address appropriate standards of behaviour in the workplace and render conduct such as bullying and harassment a breach of contract. The focus is on the way in which personal relations are carried out on a day to day basis rather than the economic elements of the bargain. Where selfemployment is concerned cases of this type might also arise and there is no reason why they should not be dealt with in the same way. Someone running a small business may well be treated in a degrading or humiliating way by the larger concern with which he trades; either by a particular individual with whom a relationship has built up or more opaquely. In any event, personals relationships emerge in a variety of relational contracts; not just the employment contract. Macneil asserts that the 'whole person' is liable to be more important in an ongoing relationship: parties 'derive complex personal non-economic satisfactions and engage in social exchange, as well as ... economic exchange'. ${ }^{65}$ It may be said though that the element of personal relations is a universal characteristic of contracts for the personal provision of work; a claim which cannot be maintained in other contexts. This may well be true but we should not disregard this dimension when it does arise elsewhere.

\footnotetext{
${ }^{65}$ Macneil, above n.40, 72.
} 
Common law developments in the law of tort are also relevant in considering how the contract for services is likely to develop. I would suggest that they also point towards convergence ${ }^{66}$ Currently, the employer owes the self-employed worker less extensive obligations in terms of health and safety than are owed to the employee. The reason why a more restricted duty is owed may be that 'the risk of accident is incidental to the contractor's enterprise rather than his employer's'. However, such an allocation of risk is based upon a set of assumptions which come under challenge from current judicial notions of enterprise liability. ${ }^{67}$ Enterprise liability seeks to attribute legal responsibility to the enterprise for activities which it has undertaken that carry risks. The pursuit of any particular activity may require the services not just of an entity's own employees but also those who contract on a different basis. It is submitted that it follows from this that the duty of care owed to, for example, a contractor's employees should be in line with that owed to the enterprise's actual employees. Both groups of staff encounter risks created by the enterprise whilst furthering its aims. It would seem equitable that parity of treatment in terms of safety obligations exist. ${ }^{68}$

Differences between the contract for employment and that for services will of course remain. The employee owes an obligation of fidelity but the contractor does not. However, an obligation of confidentiality might well be implied where the matter is not otherwise dealt with. Nevertheless, it is submitted that the overall trend is very much in favour of convergence. Scally brought about more demanding disclosure requirements within the employment relationship and there are some indications that commercial law is starting to follow suit. It appears that where a relational contract is concerned the courts have begun to impose requirements to disclose. In the Australian case of Macquarie International it was said that a party may be obliged ' to disclose information to the other, listen to the other and negotiate in good faith about the working out of the contract in its living performance. ${ }^{69}$ Similarly, in Yam Seng it was said to be arguable that the distributor was entitled to be informed of the manufacturer's best estimates of when the products would be available to sell and to be told of any

\footnotetext{
${ }^{66}$ And see Freedland, above n.2, 151-4.

${ }^{67}$ See D.Brodie, Enterprise Liability and the Common Law, (Cambridge: CUP, 2010) Ch 11.

68 The Australian decision in Stevens v Brodribb Sawmilling (1986) 160 CLR 16 can be seen as very much in line with the concept of enterprise liability.

${ }^{69}$ Macquarie International Health Clinic Pty Limited v Sydney South West Area Health Service [2010] NSWCA 268.
} 
material change in this information. The values said to underpinn relational contracts were crucial in both of these decisions as contracts of this type `may require a high degree of communication, cooperation and predictable performance based on mutual trust and confidence and involve expectations of loyalty which are not legislated for in the express terms of the contract but are implicit in the parties' understanding and necessary to give business efficacy to the arrangements. ${ }^{.70}$ I would add that disparity in bargaining power is also an important consideration as asymmetry of information about the risks of the venture and so on is more likely to arise where the resources available to the parties are decidedly unequal.

\section{The Contract of Employment Revisited}

If obligations of good faith are becoming increasingly prevalent in the law of contract as a whole what are the implications for the employment contract? I believe that the 'employment revolution' which we have witnessed over the past thirty years will gather renewed impetus and it is likely that the contract will develop further dimensions of the good faith type. The position on contracting-out may be progressed. On traditional principles, it would be possible to contract-out of the implied obligation of trust and confidence as the term is a default rule. ${ }^{71}$ The courts have been inclined to discourage any attempts at exclusion. ${ }^{72}$ It is sometimes assumed that we can be confident that derogation would be forbidden by the judiciary on grounds of public policy given that mutual trust and confidence is absolutely fundamental to the employment relationship. A recent instance of such optimism can be found in the joint advice of the Law Commissions on Unfair Contract Terms. ${ }^{73}$ The Commissions noted the argument that the decline of collective bargaining left more scope for substantively unfair terms in employment contracts. They also highlighted the concern over the potential use of express terms to contract out of the terms which

\footnotetext{
${ }^{70}$ Yam Seng, above n. 36, para 142.

${ }^{71}$ See Lord Steyn in Johnson above n. 26.

${ }^{72}$ Lord Bingham, 'Form Servant to Employee: A Study of the Common Law in Action' 13 SAcLJ 253, 266.

${ }^{73}$ Law Commission and Scottish Law Commission, 'Unfair Terms in Consumer Contracts: Advice to the Department for Business, Innovation and Skills' (March 2013) 7.125.
} 
the law would otherwise imply into employment contracts, such as the obligation of mutual trust and confidence. It was said that this was not a matter of genuine concern and the views of one consultee in particular were influential: 'I also think it is unlikely that a Court or Tribunal in the United Kingdom would uphold an apparently valid attempt to exclude the implied obligation of mutual trust and confidence. I can certainly see as a matter of first principles that any implied term could be supplanted by an express term, it is just that a Court or Tribunal would be expected to disregard such an attempt on public policy grounds there being so much authority to the effect that the implied obligation of mutual trust and confidence is an irreducible term in the employment contract because such contracts govern relationships essentially of a personal nature.' Such views also gain credence from the much more common position in other European systems whereby 'the regulation of the content and the performance of contracts of employment...more readily presents itself as jus cogens in character, its norms typically appearing to be inderogable, or derogable only in very limited circumstances. ${ }^{74}$

It is certainly the case that it would be open to the courts to render the term 'irreducible' on grounds of public policy. The emerging law on sham contracts may offer an alternative route to mandatory incorporation. In the Australian case of Russell v Trustees of the Roman Catholic Church it was said that `...if one sought to exclude, expressly, the relationship of trust and confidence, if it were a necessary and essential ingredient of employment, one may still have a contract, but it is unlikely to be a contract of employment. ... Unlike most other implied duties, it cannot be excluded unless one does not want to have a contract of employment. ${ }^{.75}$ I would submit that the reasoning in Russell is instructive. A clause which purports to exclude mutual trust in a contract which would otherwise be classified as one of employment should be set aside as it is incompatible with the nature of the contract: ` the written contract does not represent the actual terms agreed' ${ }^{76}$ Mutual trust and confidence is an obligation which is fundamental to the employment relationship and expresses the essence of the bargain.

\footnotetext{
${ }^{74}$ Freedland and Kountouris, above n. 7, 182.

75 (2008) 72 NSWLR 559 at paras 127-128. And see B.Creighton and A.Stewart, Labour Law (5 $5^{\text {th }}$ ed) 14.48.

${ }^{76}$ Autoclenz, above n. 46.
} 
Crucially, it aims to protect the employee's interest in not being 'unfairly and improperly exploited'. ${ }^{77}$ In my view, an attempt to set up an employment relationship without the term is a sham. The purported transformation of the relationship is just as radical and unacceptable as the attempt to convert employment to self-employment in Autoclen₹ or a lease into a licence in AG Securities.

The employer may seek to contract-out of particular applications of the term rather than attempt general exclusion. This will not avail him. In the recent Australian case of Barker the contract dealt expressly with a dimension of employment relations (redeployment) and declared that the matter was non-contractual. ${ }^{78}$ The Federal Court accepted that, as a result, the employer was not bound on the basis of the published policy. Nevertheless, the employer was still found to be in breach of the implied term. The view was taken that any measures which the implied term would otherwise have required if the contract had been silent on the issue in question could not be denied in this way.

The fact that notions of good faith have become much more pervasive in contract law as a whole make it more likely that mutual trust and confidence will be rendered mandatory on grounds of public policy. Good faith type obligations have become much harder to depict as exceptions to general principles or as features of particular types of contract. There is no longer a need for special pleading and there is growing acceptance that there is no other legitimate way to conduct business affairs.

\section{Conclusions}

The courts (in the UK and abroad) are increasingly willing to attribute to contracting parties an acceptance that commercial relations should be informed by fair dealing. Whether an overarching principle will emerge in the near future remains a matter of conjecture but the likelihood has increased markedly. Should that eventuality materialise the law on all forms of contracts for the provision of

\footnotetext{
${ }^{77}$ Malik, above n. 9, 46.

${ }^{78}$ Barker, above n. 1.
} 
work will be affected by the consequent transformation in values underpinning commercial contracts. For now it can be said with confidence that the laws of commercial and employment contracts are moving closer together. Moreover, there is good reason to think that, where relationships analogous to employment are concerned, good faith will undoubtedly play a significantly greater role. Numerous cases have arisen in other jurisdictions in the context of franchise relationships; partly because they frequently embody a significant disparity of bargaining power and call out for judicial activism. As with employment, terms are offered on a take it or leave it basis: 'the same agreement is intended to be used throughout the network without variation. ${ }^{, 79}$ Inequality of bargaining power means that the weaker party is at risk of oppressive treatment in the way that, for example, discretionary provisions are exercised. The emergence of mutual trust and confidence was, at least in part, inspired by concerns which were seen as unique to the employment contract. Such assumptions are very much open to debate and it would often be appropriate to extend the common law protection afforded to employees to those who provide work under other types of contract.

${ }^{79}$ J. Adams in Contract and Economic Organisation, above n.39, 8. 